\title{
Ruhsal Hastalığa Sahip Bireylere Yönelik Damgalama: Etkileyen Faktörlere ve Bireyler Üzerindeki Etkilerine Dair Kavramsal Bir Çalışma
}

\author{
DOI: $10.26466 /$ opus. 825384
}

*

\section{Seval Bekiroğlu *}

* Dr. Öğretim Görevlisi, Başkent Üniversitesi Sosyal Hizmet Bölümü

\author{
E-Posta: sbekiroglu@baskent.edu.tr \\ ORCID: 0000-0003-0712-6653
}

\section{Öz}

Geçmişten günümüze ruhsal hastalığa sahip bireyler yoğun bir şekilde damgalamaya maruz kalmıştır. Toplumda bir ruhsal hastah̆ğa sahip olmak; kişisel bir eksiklik, zayıflı, sapma, düşük zeka, güvenilmezlik veya yetersizlik belirtisi olarak görülürken, ruhsal hastahğa sahip bireyler ise şiddet gösteren ve öngörülemeyen davranışlara sahip kişiler olarak çoğu zaman görülmüştür. Bu tür olumsuz tutum ve davranışlar, bireylerin kendisi ile birlikte ailelerinde, sosyal çevrelerinde ve sağlık profesyonelleri arasında olmak üzere toplum genelinde bulunmaktadır. Damgalama biçimleri ise farklı ülkelerde veya bölgelerde neredeyse aynıdır. Damgalamanın sonucu olarak birçok ruhsal hastahı̆g sahip birey, tedavi almamayı veya tedaviyi erken birakmayı tercih etmektedir. Bu yönüyle damgalama ruhsal hastahı̆g sahip bireylere, dolayısıyla üyesi olduğu topluma zarar vererek adaletsizliklere ve yıkıcı sonuçlara yol açabilme gücüne sahiptir. Ruhsal hastalı̆̆a sahip bireylere yönelik gerçekleştirilecek damga karşıtı müdahalelerde, damgalamayı etkileyen faktörlerin dikkate alımması ve etkilerini azaltmaya yönelik müdahalelerin gerçekleştirilmesi oldukça önemlidir. Bu çalışma, damgalama ile ilişkili temel kavramları, damgalamayı etkileyen faktörleri ve damgalamanın bireyler üzerindeki etkilerini literatür desteği ile açıklamayı amaçlamıştır.

Anahtar Kelimeler: Ruhsal hastalı̆̆a sahip birey, damgalama, etkiler, faktörler. 


\title{
Stigmatization Of People With Mental Illness: A Conceptual Study on the Affecting Factors and Their Effects On People
}

\begin{abstract}
From past to present, individuals with mental illness have been subjected to intense stigma. Having a mental illness in the community was seen as a sign of personal deficiency, weakness, deviation, low intelligence, unreliability or inadequacy. Individuals with mental illness were often seen as people with violence and unpredictable behavior. These kinds of negative attitudes and behaviors are present in the society, including the individuals themselves, their families, social environment and health professionals. Stigmatization styles are almost the same in different countries and regions. As a result of stigma, many individuals with mental illnesses prefer not to receive treatment or to stop treatment early. In this respect, stigma has the power to cause injustice and destructive consequences by damaging individuals with mental illness and therefore the society. It is very important to consider the factors affecting stigmatization and to implement interventions to reduce their effects in anti-stigmatization interventions for individuals with mental illness. This study aimed to explain the basic concepts related to stigmatization, the factors affecting stigmatization and the impact of stigma on people with mental illness with the support of the literature.
\end{abstract}

Keywords: Individuals with mental illness, stigmatization, impacts, factors. 


\section{Giriş}

Tarih boyunca toplumda birçok hastalık damgalanmıştır. İlk damgalanan hastalıklardan olan cüzzam, tanrının insana verdiği bir kötülük olarak toplumda nitelendirilmiştir (Bilge ve Çam, 2010; Gary, 2005). 1300'lü yıllarda kara ölüm olarak da bilinen veba, tanrının insanlara günahkâr davranışları yüzünden gönderilen bir ceza olarak görülmüş, tanrının öfkesini yatıştırmak için toplumun normlarına aykırı yaşayan gruplar günah keçisi ilan edilmiştir. 15. yüzyılda frengiye yakalananlar tarih boyunca lanetlenmişlerdir (Bilge ve Çam, 2010; Oran ve Şenuzun, 2008). 19. yüzyılın sonlarında ve 20. yüzyılda, veremli hastaların izolasyonu için dağlık yerlerde senatoryumlar yapılmıştır (Barış, 2002). 1980'lerde ortaya çıan ve o dönemlerde homoseksüel hastalığ olarak bilinen AIDS, "Allah'in günahkârlara verdiği bir ceza" olarak yorumlanmıştır. 1900'lü yıllardan itibaren insanlar kanser tanısı almaya başlamış ve o dönemlerde kanser hastaları birçok önyargılı davranış ve ayrımcılıkla yüz yüze kalmıştır (Oran ve Şenuzun, 2008). Bu hastalıklarda görüldüğü üzere insanlar, hastalıklar hakkında bilgi sahibi olup olmama durumlarına bakmaksızın olumsuz ön yargılarla donatılmıştır. Bu tür olumsuz ön yargılardan nasibini alan hastalıkların başında ise geçmişten beri ve günümüzde de ruhsal hastalıklar gelmektedir (Üçcok, 2003). Dünya Sağlık Örgütünün (DSÖ) raporlarında sıklıkla damgalamaya en çok maruz kalan kesim arasında ruhsal hastalığa sahip bireylerin geldiği belirtilmektedir (World Health Organization, 2011). Literatürde, bütün toplumların ruhsal hastalı̆̆a sahip bireyleri damgaladığı, damgalama biçimlerinin ise farklı ülkelerde veya bölgelerde neredeyse aynı olduğu belirtilmektedir(Ciftci, Jones ve Corrigan, 2013; World Health Organization, 2011).

Halkın ruhsal hastalığa sahip bireylere ilişkin inanç, tutum ve davranışlarını inceleyen çalışmalar, genel olarak halkın bu bireylere yönelik olumsuz inanç, tutum ve davranışlara sahip olduğunu göstermektedir (Şen, Taşkın, Özmen, Ademir, ve Demet, 2003; Taskin vd., 2002; Taşkın, Şen, Özmen, ve Aydemir, 2006). Bununla birlikte çalışmalar, bu bireylere yönelik toplumun herkesiminde var olan damgalamanin ruhsal hastalığa sahip bireylerin davranışlarından çoğu zaman bağımsız olarak oluştuğunu göstermektedir (Baysal Doğanavşargil, 2013). Yani kişiler bu bireylere dair herhangi bir deneyime sahip olmadan da olumsuz düşünce, tutum ve davranışlara sahip olabilmektedir. 
Toplumda bir ruhsal hastalığa sahip olmak; kişisel bir eksiklik, zayıflık, sapma, düşük zeka, güvenilmezlik veya yetersizlik belirtisi olarak görülürken, ruhsal hastalığa sahip bireyler ise şiddet ve öngörülemeyen davranışlara sahip birileri olarak görülmektedir (Hawke, Parikh ve Michalak, 2013). Ne yazıktır ki bu tür olumsuz tutum ve davranışlar, bireylerin kendisi ile birlikte ailelerinde, sosyal çevrelerinde ve sağlık profesyonelleri arasında olmak üzere toplum genelinde de bulunmaktadır (Arkan, Bademli, ve Duman, 2011; Çam ve Bilge, 2013; Hawke vd., 2013).

Ruh sağlığı hizmetleri son yıllarda önemli ölçüde gelişmiş olsa da, Ciftci ve ark. (2013)'nın da belirttiği üzere, damgalamanın sonucu olarak birçok ruhsal hastalığa sahip birey, tedavi almamayı veya tedaviyi erken bırakmayı tercih etmektedir. Bireyler damgalamadan kaçınmak için ruhsal hastalıkları ile ilgili yardım aramamayı, dolayısıyla ruh sağlığı kliniği veya profosyonelleri ile ilişkilendirilmemeyi ve tanı almamayı tercih etmektedir (Corrigan, Roe ve Tsang, 2011). Öyle ki çalışmalar da, ruhsal hastalığa sahip bireylerin damgalamayı en yoğun yaşadığı durumlardan birisinin psikolojik yardım almaya ilişkin olduğunu göstermektedir (Goldberg ve Smith, 2011; Mak vd., 2007; Major ve O'Brien, 2005). Ruhsal hastalığa sahip bireyler yardım alma sürecinde kendini ne kadar damgalarsa veya toplum tarafından damgalanacağını ne kadar düşünürse yardım arama konusunda da kendini o kadar engellemektedir. Öte yandan yardım alma düzeyi arttıkça damgalanma o derecede azalmaktadır (Wade, Post, Cornish, Vogel ve Tucker, 2011). Bu yönüyle damgalama ruhsal hastalığa sahip bireylere, dolayısıyla üyesi olduğu topluma zarar vererek adaletsizliklere ve yıkıcı sonuçlara yol açabilme gücüne sahip olduğundan oldukça önemlidir (Ciftci vd., 2013). Damgalama sürecinin anlaşılmasında, damgalama ile ilişki temel kavramların, damgalamayı etkileyen faktörlerin ve damgalamanın bireyler üzerindeki erkilerinin bilinmesinin oldukça önemli olduğu düşünülmektedir. Buradan hareketle bu çalışma, damgalama ile ilişkili temel kavramları, damgalamayı etkileyen faktörleri ve damgalanmanın bireyleri üzerindeki etkilerini literatür desteği ile açıklamayı amaçlamıştır.

\section{Damgalama (Stigmatizasyon)}

Damgalama kuramının öncüsü Goffman (2009, p. 9) damgalamayı; "tam toplumsal kabulden diskalifiye edilen bireyin durumu (akt:Ciftci vd., 2013), 
damgalanan bireye daha az değer verme davranışı, bu etiketi taşıyan insanların daha az istenebilir ve neredeyse insan gibi algilanmaması" olarak tanımlamaktadır (akt:Bilge ve Çam, 2010; Oran ve Şenuzun, 2008).

Alanyazında ruhsal hastalığa sahip bireylerde damgalamanın, karmaşık bir fenomen olarak kavramsallaştırıldığı görülmektedir. Farklı yazarlar tarafından damgalama; basmakalıp düşünceler, önyargı ve ayrımcılık (Corrigan and Kleinlein, 2005), bilgi sorunları (cehalet veya yanlış bilgi), tutum (önyargı) ve davranış sorunları (ayrımcllı) (Thornicroft ve ark. 2007), etiketleme, stereotipler (stereotyping), duygusal tepkiler, statü kaybı ve ayrımcillğın birlikte oluşumu gibi kavramlarla tanımlanmıştır (Świtaj, Chrostek, Grygiel, Wciórka ve Anczewska, 2016). Corrigan, Roe ve Tsang (2011)'in da vurguladığ onun yapısını oluşturan tutumlar, stereotipler, önyargı ve ayrımcılık gibi temel terimleri ayırt etmek önemlidir.

İnsanlar, yaşama bakış açılarına göre şekillenen değerleri ve duygusal tepkilerine dayanan tutumlar oluştururlar (Corrigan vd., 2011). Kişilerin bakış açısı, olaylar karşısında verdikleri duygusal reaksiyonları etkiler. Bu reaksiyonlar bazen pozitif bazen de negatif olmaktadır. Kişideki bu reaksiyonlar ve dünya görüşünün bütünleşmesi ile oluşan bakış açısına "tutum" denir. Ruhsal hastalığa sahip bireylere yönelik tutumlar genellikle negatiftir (Avcil, Bulut ve Sayar, 2016). İngiltere ve ABD'de yaklaşık 2000 katılımcı ile gerçekleştirilen bir çalışmada, ruhsal hastalığa sahip bireylere yönelik tutumların; (1) korku ve dışlama (bu bireylerden korkulmalı ve bu nedenle çoğu toplumdan uzak tutulmalıdır), (2) otoriterlik (bu bireyler sorumsuzdur, hayat kararları başkaları tarafından yapılmalıdır) ve (3) yardımseverlik (bu bireyler çocuksu ve bakıma muhtaçtır) olmak üzere üç yaygın söylemde tanımlandığ1 görülmüştür (Brockington, Hall, Levings ve Murphy, 1993).

Tutumlar konusunda üç temel kavram karşımıza çıkmaktadır. Bunlar stereotip, önyargı ve ayrımcllıtır. Stereotipler, bireyleri belirli bir gruba veya kategoriye ayırmaya ilişkin sergilenen tutumlardır. Bu yönüyle stereotipler, genellikle yanlış veya yanıltıcı olan genellemelere dayanır. Toplumda ruhsal hastalığa sahip bireylere yönelik en yaygın stereotiplerin "tehlikeli" ve "ne yapacağı belli olmayan birey" olduğu söylenebilir. Önyargı, belirli gruplara yönelik olumsuz duygusal tutumları (öfke ve korku) ve aşağılayıcı stereotipleri ifade eder. Önyargılar, stereotipileri destekler ve ikisinin sonucunda 
farklı duygusal reaksiyonlar gelişebilir. Ayrımcılık, damgalamanın davranışsal bileşenidir ve insanlar önyargılı tutum veya inançlar temelinde hareket ettiğinde ortaya çıkar (Ciftci vd., 2013; Corrigan vd., 2011). Ayrımcılık toplumdaki kişi ya da grupların diğerlerini damgalama ve önyargı nedeniyle bazı hak ve menfaatlerden yoksun bırakmasıdır (Bilge ve Çam, 2010; Üçok, 2003). Bilge ve Çam (2010)'a göre damgalama bir düzlem üzerinde gerçekleşseydi, ilk adım etiketleme son adım ise ayrımclık olurdu.

Alanyazında ruhsal hastalığa sahip bireylerde damgalama türlerini tanımlamada terminolojik ayrımların olduğuna rastlanmaktadır. Bazı çalışmalarda damgalama; algılanan, deneyimlenen ve kendini damgalama olmak üzere üç düzeyde tanımlanmaktadır (Brohan, Elgie, Sartorius, ve Thornicroft, 2010; Gerlinger vd., 2013; Świtaj vd., 2016). Bazı çalışmalarda; yapısal/kamusal, sosyal ve içselleştirilmiş damgalama olmak üzere üç düzeyde tanımlanmaktadır (Corrigan ve Watson, 2002; Hawke vd., 2013; Livingston ve Boyd, 2010). Gerlinger ve ark. (2013)'nın ise üç düzeyde tanımlanan damgalama türlerini birleştirerek sosyal ve kişisel damgalama (algilanan, deneyimlenen ve kendini damgalama/içselleştirilmiş damgalama) olmak üzere iki düzeyde ele aldığı görülmektedir.

Ruhsal hastalığa sahip bireylerin en yoğun yaşadığı damgalama türü olan algılanan damgalama; bireyin yaşadığı toplum içerisinde hangi gruba dahil olduğuna ve damgalanmış bir grubun üyesi olarak kendisini görmeye ilişkin inancın ifade etmektedir (Dickerson, Sommerville, Origoni, Ringel, ve Parente, 2002; Gerlinger vd., 2013). Deneyimlenen damgalama, reddedilme ve ayrımcılıkla fiilen karşılaşma olarak tanımlanmaktadır. Kendini damgalama veya içselleştirilmiş damgalama; ruhsal hastalığa sahip bireylerin toplumda kendilerine yönelik var olan olumsuz tutum, inanç ve davranışları benimsemesi, kabul etmesi ve bunun sonucunda benlik saygisında ve öz-yeterlikte azalma ile kişilerin kendilerini toplumdan geri çekmesi olarak tanımlanmaktadır (Brohan vd., 2010; Gerlinger vd., 2013; Świtaj vd., 2016). Kendini damgalama, damgalanmış bir gruba ait bireyler kamusal önyargıyı içselleştirdiğinde ve bunu kendilerine yönlendirdiğinde ortaya çıkar (Ciftci vd., 2013). Bu yönüyle kendini damgalamanın, sıklıkla kamusal/yapısal damgalanmanın sonucu olduğu söylenebilir.

Yapısal/kamusal damgalama ise; ruhsal hastalığa sahip bireylerin haklarını ve fırsatlarını sistematik bir şekilde kısıtlayan, iktidar konumundaki kurumların politikalarına ve uygulamalarına atffta bulunmaktadır (Livingston ve 
Boyd, 2010). Bu damgalama, bireylerin istihdama, eğitim olanaklarına, sağlık hizmetlerine ve barınmaya erişimini engelleyen önyargı ve ayrımcllıtır. Kamusal/yapısal damgalama, genel halk ruhsal hastalıklar hakkındaki stereotipleri onayladığında ve bu stereotiplere dayanarak hareket ettiğinde ortaya çıkar (Ciftci vd., 2013). Bu yönüyle sosyal damgalamanın bir sonucu olduğu söylenebilir. Öyle ki sosyal damgalama, genel halkın damgalanmış durumdaki ruhsal hastalığa sahip bireyler hakkındaki stereotipleri onaylamaları, bu bireylere karşı önyargılı olması ve ayrımclık göstermesini ifade etmektedir (Corrigan, Watson ve Barr, 2006; Gerlinger vd., 2013). Yapısal ayrımcılığın en ileri ve acımasız biçimine dair Nazi Almanya'sında 1933-1945 yılları arasında "Kalıtsal hastalıkları önleme yasası" doğrultusunda yaklaşık 200-260 bin dolayında ruhsal hastalığa sahip bireyin psikiyatristlerin gözetiminde öldürülmesi örneği verilebilir (Torrey ve Yolken, 2010).

Ruhsal hastalığa sahip bireylerde damgalama ile ilişkili göz önünde bulundurulması gereken önemli nokta; ruhsal hastalıklar hakkında korku, yanlış inançlar ve olumsuz tutumlardan kaynaklanan, kalıp yargılarla hastalığın gerçekte nasıl bir durum olduğunun diğerleri tarafından anlaşılmasını güçleştiren bir mesele olduğudur (Baysal Doğanavşargil, 2013).

\section{Damgalamayı Etkileyen Faktörler}

Toplumda ruhsal hastalığa sahip bireylere yönelik damgalamaya etki ettiği düşünülen önemli faktörler; bireysel faktörler, hastalık süreci ile ilişkili faktörler, sosyal çevre ve medya başlıkları altında ele alınabilir.

\section{Bireysel faktörler}

Damgalanmayı etkileyen en önemli bireysel faktörlerin başında damgalanma algısının geldiği söylenebilir. Damgalanma algısı, ruhsal hastalığa sahip bireylerin dış çevreden gelen olumsuz tutum ve davranışların etkisiyle ya da hiçbir uyarı olmaksızın kendisini damgalanmış bir grubun üyesi olarak görmesiyle ilişkilidir. Bu yönüyle bireyler, açıkça damgalayıcı bir tutum ve davranışla karşılaşmasalarda dahi damgalanmışlık duygusu taşıyabilmektedir (Baysal Doğanavşargil, 2013). Bununla birlikte çalışmalar, ruhsal ruhsal hastalığa sahip bireylerin bir kez kendileri ya da başkaları tarafından "akıl hastasi" olarak etiketlendiklerinde istemeyerek de olsa kendilerini bu grubun bir 
üyesi olarak görme eğiliminde olduğunu göstermektedir. Dolayısıyla olumsuz kalıp yargılar içselleştirilerek bireylerin kendileri için de geçerli "gerçekler" haline gelmekte ve kişide utanç duygusuna yol açmaktadır (Bilge ve Çam, 2010; Ersoy ve Varan, 2007).

Ruhsal hastalığa sahip bireylerin sosyodemografik özellikleri ile damgalama arasındaki ilişkiyi inceleyen çalışmalar çelişkilidir. Bireylerin medeni durumu, yaşı, eğitim düzeyi, çalışma durumu, mesleği, gelir düzeyi ile damgalanma arasında anlamlı ilişkinin olmadığı yapılan birçok çalışmada bildirilmiştir (Bekiroğlu ve Demiröz, 2020a; Dickerson vd., 2002; Gerlinger vd., 2013; Sibitz vd., 2011; Świtaj vd., 2009). Bununla birlikte Zarringer (2002); eğitim seviyesi yüksek, yüksek bir pozisyonda çalışan ve genç olan ruhsal hastalığa sahip bireylerin algıladıkları damgalanmanın daha yüksek olduğunu bildirmiştir (akt: Doğanavşargil Baysal, 2013). Yine yaş arttıkça ruhsal hastalığa sahip bireyler de içselleştirilmiş damgalanmanın azaldığını gösteren çalışmalar (Karidi vd., 2010; Lysaker, Tsai, Yanos, ve Roe, 2008) bulunmakla birlikte çoğu çalışmada, içselleştirilmiş damgalanma ile yaş arasında ilişkinin olmadığ bildirilmiştir (Gerlinger vd., 2013).

Bazı çalışmalar, ruhsal hastalığa sahip bireylerin cinsiyetleri ile damgalama arasındaki ilişkiye dikkat çekerken (Bekiroğlu ve Demiröz, 2020a) bazı çalışmalar (Gerlinger vd., 2013; Sibitz vd., 2011; Świtaj vd., 2009) cinsiyetle damgalanma arasında ilişkinin olmadığını belirtmektedir. Bekiroğlu ve Demiröz (2020a) çalışmalarında, erkeklerin kadınlara göre psikolojik yardım alma nedeniyle toplum tarafından damgalandığına ilişkin algısının daha yüksek olduğunu saptamıştır. Bu durum çalışmada, erkeklerden beklenen toplumsal cinsiyet rollerinin (erkeğin çalışan ve eve para getiren kişi rolü) etkisi ile sosyal hayata daha fazla katılım sağlamak zorunda kalması ve bunun sonucu olarak damgalayıcı davranış ve tutumları daha çok yaşaması ile açıklanmıştır.

West, Yanos, Smith, Roe, and Lysaker (2011) çalışmalarında, ruhsal hastalığa sahip bireylerin yaş dışındaki sosyodemografik özellikleri ile içselleştirilmiş damgalanma düzeyleri arasında ilişkinin olmadığını bildirmiştir. Çalışmada, orta yaş grubundaki bireylerin (34-54 yaş) daha genç ve daha yaşlı grubundaki bireylere göre daha yüksek içselleştirilmiş damgalanmaya sahip olduğu bildirilmiştir. Bu durum çalışmada, orta yaştaki bireylerin kişisel istekleri ve onları başarmak için sahip oldukları engellerle birlikte içselleştirilmiş damgalamadan daha çok etkilenmiş olma ihtimali ile açıklanmıştır. Bununla 
birlikte başka bir çalışmada daha genç, daha düşük gelir ve eğitim seviyesine sahip ruhsal hastalığa sahip bireylerde içselleştirilmiş damgalamanın daha yüksek olduğu bildirilmiştir (Werner, Stein-Shvachman, ve Heinik, 2009).

Kişilerin yaşam biçimi ile damgalama arasındaki ilişkiyi inceleyen çalışma sonuçları çelişkilidir. Bekiroğlu ve Demiröz (2020a) çalışmalarında, birileri yaşayan ruhsal hastalığa sahip bireylerin yalnız yaşayanlara göre daha yüksek damgalama düzeyine sahip olduğunu göstermektedir. Bu durum birileri ile yaşayan kişilerin, yakın çevreleri tarafından maruz kaldıkları olumsuz tutum ve davranışlar ile birlikte damgalanmayı daha yoğun yaşamaları ile açıklanabilir. Öte yandan yaşam biçimi ile damgalanma arasında ilişkinin olmadığını belirten çalışmalar da mevcuttur (Świtaj vd., 2016).

Ruhsal hastalığa sahip bireylerin benlik saygısı, damgalamayı etkileyen önemli faktörlerden bir diğeridir. Düşük benlik saygısına sahip bireylerin algiladıkları ve içselleştirilmiş damgalanma düzeylerinin daha yüksek olduğu çalışmalarla ortaya konmuştur (Werner vd., 2009; Yanos, Roe, Markus, ve Lysaker, 2008).

Özetle damga karşıtı müdahalelerde, kişilerin damgalanma algısı, sosyodemografik özellikleri, yaşam biçimi ve benlik saygısı gibi bireysel faktörlerinin damgalanma durumları üzerindeki etkisi göz önünde bulundurulmalıdir.

\section{Hastalık süreci ile ilişkili faktörler}

Hastalık tanısına göre ruhsal hastalığa sahip bireylerin maruz kaldığı damgalanma düzeyi değişmektedir. Çalışmalar, ruhsal hastalığa sahip bireyler içerisinde en çok şizofreni hastalığına sahip bireylerin damgalandığını göstermektedir (Bilge ve Çam, 2010; Çam ve Bilge, 2013). Arslantaş ve ark. (2010) çalışmalarında, şizofreni hastalığına yapılan damgalamanın depresyon, anksiyete ve diğer ruhsal hastalıklara oranla daha fazla olduğunu ortaya koymuştur. Baysal Doğanarşavgil (2013)'e göre bir ruhsal bozukluğun toplumda fark edilmesi ve dikkat çekmesi ne kadar çoksa, toplum tarafından damgalanması da o denli çok olmaktadır. Toplumsal olarak yadırganan, garip, acayip bulunan, saldırgan ve tehlikeli davranışlar, kişinin toplumsal ve mesleki işlevlerini yerine getirmedeki yetersizlikleri ve bedenselleştirme gibi davranışlar damgalamayı kolaylaştırmaktadır. 
Bir ruhsal hastalık tanısı toplum tarafindan ne kadar biliniyorsa damgalama o derece fazladır. Burada hastalığın toplum tarafından bilinmesinin altında yatan anlam, hastalık hakkındaki bilgi düzeyi değildir. Hastalığın toplumda çağrıştırdığı anlamdır. Örneğin, sokakta geçen herhangi birine "Şizofreni nedir?" diye sorulunca kişilerin söyleyebilecekleri bir şeyler varken, “Bipolar bozukluk nedir?" diye sorulunca insanlar bu hastalı̆̆ daha önce çok fazla duymadıklarından söyleyecekleri şeylerin daha az olduğu söylenebilir. Sokaktaki insanın gözünde şizofreni neredeyse deliliğin diğer adıdır (Üçok, 2003). Bu yönüyle toplumda şizofreniye yönelik damgalama eğiliminin, gerçekte şizofreninin nasıl bir hastalık olduğuna dair bilgi eksikliğinden kaynaklı yanlış inanışlarla ilişkili olduğu söylenebilir.

Hastalık tanısının damgalayııı içeriği ne kadar fazla ise kişiler de kendilerini o derece damgalamaktadır. Utanma ve yetersizlik duygularındaki artısla birlikte ruhsal hastalığa sahip bireylerin benlik saygıları azalmakta, bireyler sosyal ilişkilerden kaçınır hale gelmektedir (Avcil vd., 2016; Baysal Doğanavşargil, 2013; Taşkın, 2007). Öyle ki Lysaker ve ark.(2008), ruhsal hastalığa sahip bireylerin hastalıklarına ilişkin farkındalığının yüksek olmasının işlevselliklerini arttırken, bu farkındalığa damgalayıcı tutumların algılanması ve kabulünün eşlik ettmesinin işlevselliklerini ciddi anlamda azalttığının altını çizmektedir. Bununla birlikte çalışmalar, içselleştirilmiş damgalanmanın bipolar bozukluğu olan bireylerde daha fazla olduğunu göstermektedir (Çam ve Bilge, 2013).

Hastalık süreci (hastalık süresi, pozitif/negatif belirtiler, tedavi ortamı, belirti şiddeti, yatış sayısı, hastalığa dair içgörü) ile damgalama arasındaki ilişkiyi inceleyen çalışma sonuçları çelişkilidir. Çalışmaların çoğunda hastalık süreci ile damgalama arasında ilişkinin olmadığı bildirilmiştir (Gerlinger vd., 2013; Świtaj vd., 2016). Bireylerin algıladıkları ve deneyimledikleri damgalama ile hastalık süreleri arasında anlamlı ilişkinin bulunmadığını bildiren çalışmalara (Bekiroğlu ve Demiröz, 2020a; Gerlinger vd., 2013; Sibitz vd., 2011; Świtaj vd., 2009) karşın, içselleştirilmiş damgalama ile hastalık süresi arasında pozitif ilişkinin bulunduğun bildiren çalışmalar bulunmaktadır (Coşkun ve Güven Caymaz, 2012). Bireylerin hastalık süreleri arttıkça içselleştirilmiş damgalama düzeyleri artmaktadır. Yine hastaneye yatış durumu ile içselleştirilmiş damgalama arasında pozitif ilişkinin olduğu çalışmalarda bildirilmiştir (Coşkun ve Güven Caymaz, 2012). 
Üstündağ ve Kesebir (2013) çalışmalarında, içselleştirilmiş damgalaması yüksek olan iki uçlu bozukluğa sahip bireylerin işlevsellik puanlarının daha düşük, iyilik dönemlerinin daha kısa, depresif dönem sayılarının daha fazla olduğunu bildirmiştir. İçselleştirilmiş damgalamanın iki uçlu bozukluğun klinik özellikleri ile etkileştiğine, yaşam kalitesi ve tedavi uyumunda fark yarattığı çalışmada vurgulanmıştır.

Sonuç olarak hastalık tanısı, hastalık tanısının toplumca bilinme düzeyi ve damgalayıcı içeriğe sahip olması, hastalık süresi, pozitif/negatif belirtiler, tedavi ortamı, belirti şiddeti, yatış sayısı, hastalığa dair içgörü gibi hastalık sürecine ilişkin özellikleri barındıran faktörlerin bu bireylerin yaşadıkları damgalanma üzerindeki önemli etkisi göz ardı edilmemelidir.

\section{Sosyal çevre}

Ruhsal hastalığa sahip bireylere yönelik damgalama sadece ülkemizde değil, tüm dünyada önemli bir sorundur. Bununla birlikte damgalamanın etkileri, boyutları ve sonuçları yerel bağlamda büyük ölçüde farklılık göstermektedir (Yang vd., 2007). Örneğin Çin kültüründe ruhsal hastalık sadece bireyi değil, aynı zamanda aileyi de kirleten bir şey gibi değerlendirilmektedir. Çinli aileler, ruhsal hastalığa sahip bireyin varlığını çevrelerinden sakladıkları gibi, bireylerin de kendini damgalama düzeyinin daha yüksek olduğu bilinmektedir (Phillips, Pearson, Li, Xu, ve Yang, 2002). Amerika' da aileler ruhsal hastalığa sahip bireyleri kurum bakımına terkederken, Hindistan'da aile onuru, utanç ve ahlaki sorumluluk algısıyla aileler ruhsal hastalığa sahip bireyin bakım rolünü üstlenerek onları evlerinde saklamaktadır (Marrow ve Luhrmann, 2012). Benzer şekilde ülkemizde de ruhsal hastalığa sahip bireylerin ailelerinin güçlü bir utanç duygusu yaşadığı bilinmektedir (Ciftci vd., 2013; Özbaş, Küçük, ve Buzlu, 2008; Üçok, 2003). Çoğunlukla babaların anneleri ruhsal hastalığa sahip bir çocuk dünyaya getirdiği için suçladığı bilinmektedir.

Ruhsal hastalığa sahip bireylere yönelik damgalamada, kişilerin yaşadıkları fiziksel çevre önemli risk ve koruyucu faktörleri içerisinde barındırmaktadır. Kentsel alanlara göre kırsal kesimde yaşayan halk bu bireyleri daha fazla damgalama eğilimindedir. Hastalığı tanımak, kırsal ve kentsel kesimde farklı olmamasına rağmen hastalıkları "akıl hastalı̆̆ı" ile ilişkilendirmek kırsal kesimde daha fazladır. Bu yönüyle kırsal kesim, ruhsal hastalıkları ve bu 
hastalıklara sahip bireyleri kentsel kesime göre daha çok etiketleme eğilimindedir (Şen vd., 2003; Taskin vd., 2002). Sosyal mesafe ve sosyal reddedilme gibi olumsuz tutumlar kırsal kesimde daha belirgindir (Şen vd., 2003). Dolayısıyla kırsal alanda yaşayan ruhsal hastalığa sahip bireyler, kentsel alanlarda yaşayanlara göre daha çok damgalamaya maruz kalmaktadır (Çam ve Bilge, 2013; Şen vd., 2003; Taşkın vd., 2006). Bu yönüyle yaşanılan fiziksel çevre damgalamada önemli faktörlerden biridir.

Yaşanılan yerdeki kişilerin eğitim seviyesi, damgalamada sosyal çevrenin barındırdığı damgalamayı etkileyen diğer faktörlerden biridir. Çalışmalar, ruhsal hastalığa sahip bireylerin, düşük sosyoekonomik ve eğitim düzeyindeki kişilerden oluşan bir sosyal çevrede damgalanmaya daha çok maruz kaldığını göstermektedir. Eğitim ve sosyodemografik düzey düştükçe bu bireylere yönelik yaklaşım daha olumsuz olabilmektedir. Özellikle alt ekonomik düzeydeki bireylerin ruhsal hastalıkları daha çaresizce karşıladıkları, tehlikeli gördükleri ve olumsuz inanca sahip oldukları bilinmektedir. Bununla birlikte, üst ekonomik düzeydeki bireylere (daha fazla korku ve dışlama) göre orta ekonomik düzeydeki bireylerin ruhsal hastalı̆̆a sahip bireylere yönelik daha olumlu tutum ve davranışlara sahip olduğu bilinmektedir (Baysal Doğanavşargil, 2013; Çam ve Bilge, 2011; Çam ve Bilge, 2013; Şen vd., 2003; Taskin vd., 2002).

Bireylerin yaşadığı sosyal çevrede ruhsal hastalıklara dair bilgi düzeyi damgalamayı etkileyen faktörlerden bir diğeridir. Çalışmalar hastalıklara ilişkin bilgi düzeyi arttıkça damgalamanın azaldığını göstermektedir (Çam ve Bilge, 2013). Bu bireyler toplum tarafından; tehlikeli, dengeleri tamamen bozuk, ne zaman ne yapacakları belli olmayan, çevresindekilere zarar veren ve iletişim sorunu olan kişiler olarak düşünülmektedir. Özellikle yanlış inanışlarla birlikte ruhsal hastalığa sahip bireylere yönelik hissedilen korkunun en çok damgalamaya neden olduğu göz önünde bulundurulduğunda, hastalıklar hakkındaki bilgi düzeyi artıkça korkunun azaldığı, dolayısıyla damgalamanın da azaldığı söylenebilir. Bununla birlikte bilgi düzeyi arttıkça ruhsal hastalığın bir hastalık olarak algılanması da söz konusu olduğundan damgalamada azalmaktadır (Bilge ve Çam, 2010; Taşkın, 2007).

Genel halkın ve sağlık çalışanlarının yanı sıra ruhsal hastalığa sahip bireyler yakınları tarafından da yoğun damgalanmaya maruz kalmaktadır. Çalışmalar, ruhsal hastalığa sahip bireylerin yakın çevrelerinin (aileleri, akraba- 
ları) bu bireyleri saldırgan olarak tanımladığını ve ailede ruhsal hastalığa sahip bir bireyin varlığından utanıldığını, kendi hayatları hakkında doğru kararlar alamayacaklarını düşündüklerini ve benzer hastalığa sahip biriyle evlenmek istemeyeceklerini göstermektedir (Bekiroğlu ve Demiröz, 2020a; Çam ve Bilge, 2013; Özbaş vd., 2008). Bununla birlikte çalışmalar, çekirdek ailelerin ruhsal hastalıkları geniş ailelere oranla daha az kabullendiklerini, yüksek mesleki pozisyona sahip ebeveynlerin ruhsal hastalığa sahip çocuklarını daha fazla damgalama eğiliminde olduğunu göstermektedir (Dickerson vd., 2002). Hasson Ohayan ve ark. (2011), iç görüsü yüksek anne-babaların çocuklarının daha fazla hastalık yükü hissettiklerini, bu durumunda içselleştirilmiş damgalanmalarının yüksek olması ile ilişkili olduğunu ortaya koymuştur.

Öte yandan ruhsal hastalığa sahip bireylerin yanı sıra aileleri de ailede ruhsal hastalığa sahip bir bireyin varlığından ötürü toplum tarafından damgalanmaktadır (Özbaş vd., 2008; Üçok, 2003). Ailelerin bir yandan çocuklarının, kardeşlerinin hastalığından kendilerini sorumlu tutarak suçladığı, diğer taraftan toplumun ise aileleleri yüz kızartıcı bir suç işlemiş gibi suçladığı ve dışladığı bilinmektedir. Aileler çevrenin gözünde "bir şizofrenin çocuğu, annesi ya da babası" olmanın getirdiklerine göğüs germektedirler (Üçok, 2003).

Damgalamada önemli çevresel faktörlerden bir diğeri de, bireylerin sahip oldukları sosyal destek sistemleridir. Çalışmalar, ruhsal hastalığa sahip bireylerin sosyal destek düzeyi arttıkça damgalamanın azaldığını göstermektedir (Bekiroğlu ve Demiröz, 2020a; Gerlinger vd., 2013; Hawke vd., 2013). Bu yönüyle bireylerin algıladıkları sosyal desteğin yüksek olması, damgalamada önemli koruyucu faktörlerin başında gelmektedir. Öyle ki Davis ve Brekke'nin (2014) de belirttiği üzere, başlarda ruhsal hastalığa sahip bireylerin hastalık süreci ile baş etme denildiğinde daha çok negatif semptomlara ve hastalığın belirtilerine odaklanılırken şimdilerde yapılan birçok çalışma; hastalığın tedavisi, kişilerin tedaviye uyumu, yaşam kalitesi ve sosyal işlevselliği ile sahip olduğu pozitif ilişki nedeniyle sosyal destek sistemlerine odaklanmaktadır.

Özetle sosyal çevre; kültür, kişilerin yaşadıkları fiziksel çevre, yaşanılan yerdeki kişilerin eğitim seviyesi, ruhsal hastalıklara dair bilgi düzeyi, yakınları tarafından damgalama durumu ve bireylerin sahip oldukları sosyal destek sistemleri gibi ruhsal hastalığa sahip bireylerde damgalanmayı etkileyen önemli unsurları içermektedir. 


\section{Medya}

Toplumun genelinde ruhsal hastalı̆̆a sahip bireylere yönelik var olan olumsuz inanç, tutum ve davranışların oluşmasında film, gazete, radyo programları, kitaplar, reklamlar ve televizyon şovları gibi medya araçlarında yer alan bu bireylere yönelik yanlış bilgilendirme ve damgalamanın önemli katkısı bulunmaktadır. Medya, başta şizofreni olmak üzere ruhsal hastalıkları damgalayan meteryallerle doludur. Ruhsal hastalığa sahip bireylere yönelik söylemlerin yer aldığı medya analizlerinin incelendiği bir çalışmada (Corrigan, 1998); "ruhsal hastah̆ga sahip bireyler korkulması gereken cinayet manyaklarıdır", "dünyaya hayranlık duymaları gereken çocuk algısına sahiptirler ya da isyankarlardır", "eğitilmesi gereken özgür ruhlar vardır" şeklindeki üç yaygın yanlış algının temsil edildiği belirtilmiştir (Corrigan, 1998).

Özellikle şizofreniye yönelik damgalama ile medyada daha sık karşılaşılmaktadır (Bilge ve Çam, 2010). Haberler, sansasyonel suçları işleyen bireylerde bunun nedeninin bir ruhsal hastalık olduğunu vurgulamaktadır. Komedyenler, ruhsal bozukluğu olan bireylerin yetersizliklerini mizah aracı olarak kullanırlar (Avcil vd., 2016). Ülkemizde, Şahan Gökbakar'ın “Recep İvedik" film serisinde özellikle şizofren bireylere yönelik gerçekleştirilen olumsuz atıflar buna örnek verilebilir.

Toplum yazılı ve görsel medya aracılı̆̆ ile çoğu zaman ruhsal hastalıkları ve bu hastalığa sahip kişileri tanımaktadır. Bu yönüyle aslında medya, ruhsal hastalıklar hakkında toplumu bilgilendirmede değerli ve etkili bir kaynaktır. Ancak medya çoğu zaman ruhsal hastalıklar ve bu hastalıklara sahip kişiler hakkında yanlış bilgi ve yorumlamalarda bulunmaktadır. Medyada, yapılan yanlış bilgilendirme veya yorumların tekrarlanması ile izleyicinin zihninde ruhsal hastalığa sahip bireylere ilişkin yanlış algılar oluşmaktadır. Bu yönüyle güçlü bir ikna ve yönlendirme etkisine sahip kitle iletişim araçları damgalama üzerinde oldukça önemli etkiye sahiptir (Bilge ve Çam, 2010).

Medyada bu bireylere yönelik yanlış bilgilendirme ve yönlendirme ile birlikte ruhsal hastalığa sahip bireyler, toplumda yoğun ayrımcılığa maruz kalmaktadır. Bu durum ruhsal hastalığa sahip bireylerin benlik saygısının azalmasına, toplumsal hayata katılmaya ilişkin korkuya ve sosyal fırsatların (örneğin, ev sahipleri ruhsal hastalığa sahip bireylere daire kiralamakta tereddüt eder) kaydına neden olur (Corrigan, 1998). 


\section{Damgalamanın Etkileri}

Toplumda ruhsal hastalığa sahip bireylere yönelik var olan olumsuz inanç, tutum ve davranışların bireylerin sosyal hayatlarında (evlenme, çalışma, komşuluk ilişkileri vb.) ve başta sağlık hizmetleri olmak üzere hizmetlere erişim ve hizmetleri alma sürecinde birçok sorun ile karşılaşmalarına neden olduğu bilinmektedir (Gerlinger vd., 2013).

Alanyazında algılanan/deneyimlenen damgalamanın ruhsal hastalığa sahip bireylerin; depresyon (Sibitz vd., 2011; Świtaj vd., 2016) ve kaygı düzeyini arttırdığı (Birchwood vd., 2007), gizlilik ve başa çıkma stratejisi olarak sosyal hayattan daha fazla geri çekilmelerine neden olduğu (Kleim vd., 2008), yaşam kalitesini (Świtaj vd., 2016), öz-yeterliliğini (Kleim vd., 2008), benlik saygısını (Lysaker vd., 2008) ve sosyal işlevselliğini azalttı̆̆ (Bekiroğlu ve Demiröz, 2020b) bildirilmiştir (Gerlinger vd., 2013).

Genel halk, sağlık çalışanları ve yakınları tarafından yoğun damgalanmaya maruz kalmalarının doğal bir sonucu olarak ruhsal hastalığa sahip bireyler de kendilerini damgalamaktadır. Toplumsal tutum, davranış ve ayrımcı uygulamaların bireyler tarafından içselleştirilmesi, kabul edilmesi ve onaylanması ile ruhsal hastalığa sahip bireyler de kendilerini damgalamaktadır. Yapılan çalışmalar içselleştirilmiş damgalanmanın bu bireylerde oldukça yüksek olduğunu göstermektedir (Çam ve Bilge, 2013; Tel ve Ertekin Pınar, 2012). İçselleştirilmiş damgalanmanın ise bireylerin yaşam kalitesini (Switaj vd., 2016; Üstündağ ve Kesebir, 2013), benlik saygısını, (Corrigan vd., 2006; Lysaker vd., 2008; Tel ve Ertekin Pınar, 2012; Werner vd., 2009), sosyal ilişkilerini (Yanos vd., 2008), sosyal işlevselliğini (Gerlinger vd., 2013; Livingston ve Boyd, 2010; Lysaker, Vohs ve Tsai, 2009), tedaviye uyumunu (Üstündağ ve Kesebir, 2013) ve tedavi alma isteğini, algıladıkları sosyal desteği ve umut düzeyini azalttığı, depresyon ve kaygı düzeyini arttırdığı bilinmektedir (Sibitz vd., 2011).

Çalışmalar ruhsal hastalığa sahip bireylerin damgalanmayı en yoğun yaşadığ 1 durumlardan birisinin psikolojik yardım almaya ilişkin olduğunu göstermektedir (Goldberg ve Smith, 2011; Mak vd., 2007; Major ve O'Brien, 2005). Öyle ki, ruhsal hastalığa sahip bireyler yardım alma sürecinde kendini ne kadar damgalarsa veya toplum tarafından damgalanacağını ne kadar düşünürse yardım arama konusunda da kendini o kadar engellemektedir. Öte 
yandan yardım alma düzeyi arttıkça damgalanma o derecede azalmaktadır (Wade, Post, Cornish, Vogel ve Tucker, 2011).

Bireylerin damgalanmayı en yoğun yaşadığı durumlardan bir diğeri ise çalışma hayatıdır. Damgalanma, bireylerin benlik saygısını azaltarak bir işte çalışma isteğini azaltmakta, bu durumda mesleki işlevselliğini olumsuz etkilemektedir (Lysaker ve ark. 2007). Bireylerin çalışma hayatında karşılaştıkları olumsuz tutum ve davranışların onların mesleki işlevselliğinin azalmasına neden olarak sosyal işlevselliğini olumsuz etkilediği bilinmektedir (Yanos vd., 2008).

Damgalanma, bu bireylerin hizmete erişiminde bir engel oluşturduğu gibi alınan hizmetin etkinliğini de önemli derecede etkileme özelliğiyle tedavi sürecini olumsuz etkilemektedir. Bireylerde damgalanma düzeyi arttıkça kişilerin tedavi hizmetine daha az başvurduğu, bu durumunda hastalı̆̆ın seyrini olumsuz etkilediği bilinmektedir. Özellikle hastalıkla birlikte kişilerde görülen sosyal ilişki kurmada isteksizliğin tedavi almayı aksatarak bu kişileri olumsuz etkilediği bilinmektedir (Bekiroğlu ve Demiröz, 2020b).

Ruhsal hastalığa sahip bireyler, genelde kendilerine karşı toplumda var olan olumsuz stereotipilerin farkındadırlar. Bu stereotipilerin bireyler tarafından kabullenilmesi, benimsenmesi ve uygulanması ile birlikte bireylerin benlik saygısında ve öz yeterliliğinde önemli derece azalma yaşanmaktadır (Ersoy ve Varan, 2007). Bu yönüyle damgalama, ruhsal hastalığa sahip bireylerin benlik saygılarını azaltarak (Kök ve Demir, 2018; Lysaker vd., 2007) kendilerini toplumun bir üyesi olarak hissetmesini engellemektedir. Dolayısıyla, bireylerin toplumsal hayattan giderek daha fazla kaçınır hale gelmelerine neden olmaktadır (Gerlinger vd., 2013). Bireylerin kendilerini toplumdan daha çok soyutlayarak küçük bir çevreye hapsetmesi, sosyal hayata katılımını azaltması, damgalanma nedeniyle tedavi hizmetine daha az başvurması sosyal işlevselliklerini olumsuz etkilemektedir (Bekiroğlu ve Demiröz, 2020b; Gerlinger vd., 2013; Hawke vd., 2013; Livingston ve Boyd, 2010).

Damgalamanın içselleştirilmesi ile bireyler, utanç duygusunu yoğun yaşayarak toplumsal hayattan kendilerini çekebilmektedir. Bireylerin bağımsız yaşama ya da bir işte çalışma gibi hedefleri gerçekleştirme motivasyonu azalmaktadır. Toplum tarafından değersiz göründügünü düşünen bireyler yaşadıkları korku ile bir baş etme yöntemi olarak toplumsal hayata katılmaktan kaçınır hale gelebilmektedir. Bu yönüyle ruhsal hastalığa sahip bireylerde suçluluk, değersizlik düşüncesi, özsaygıda azalma, sosyal içe çekilme gibi 
depresyon belirtileri ortaya çıabilmekte ve var olan tabloya ikincil bir depresyon tablosu eklenmektedir (Avcil vd., 2016; Ersoy ve Varan, 2007).

\section{Sonuç}

Ruhsal hastalığa sahip bireyler damgalanmanın her biçimini yoğun olarak yaşamaktadır. Ruhsal hastalığa sahip bireylerin yaşadığı damgalanma biçimleri; bazı çalışmalarda algılanan damgalanma, deneyimlenen damgalanma ve içselleştirilmiş damgalanma, bazı çalışmalarda ise kişisel, sosyal ve yapısal damgalanma olmak üzere üç düzeyde sınıflandırılmaktadır. Farklı sınıflandırmalara karşın ne yazıktır ki ruhsal hastalığa sahip bireylere yönelik damgalama, bireylerin kendisi ile birlikte ailelerinde, sosyal çevrelerinde ve sağlık profesyonelleri arasında olmak üzere toplum genelinde yaygındır.

Toplumda ruhsal hastalığa sahip bireylere yönelik damgalamaya etki ettiği düşünülen önemli faktörler; sosyal çevre, bireysel faktörler, hastalık süreci ile ilişkili faktörler ve medyadır. Ruhsal hastalığa sahip bireylere yönelik gerçekleştirilecek damga karşıtı müdahalelerde, damgalamayı etkilediği düşünülen bu faktörlerin göz önünde bulundurulması ve etkilerini azaltmaya yönelik müdahalelerin gerçekleştirilmesi oldukça önemlidir.

Damgalanmanın bireylerin yaşam kalitesi, sosyal işlevselliği, benlik sayg1, kaygı düzeyi, depresyon durumu, hastalık süreci, tedavi süreci, sosyal destek ve umut düzeyi üzerinde birçok olumsuz etkisi bulunmaktadır. Bireylerin hayatı üzerinde ciddi etkileri olan damgalamayla etkin müdahale bireylerin önemli gereksinimleri arasındadır.

Hem damgalanmayı etkileyen faktörler, hem de damgalanmanın bireyler üzerindeki etkileri, damga karşıtı müdahalelerin mikro, mezzo ve makro düzeyde olmak üzere çok boyutlu gerçekleştirilmesinin gerekliliğini vurgular niteliktedir. Bu anlayışla, tek başına bireye yönelik gerçekleştirilecek müdahalelerin damgalama ile mücadelede etkili olamayacağı, eksik kalacağı söylenebilir. Bireye ve bireyin bağlantılı bulunduğu tüm sistemlere (aile sistemi, sağlık sistemi, sosyal çevre, medya) yönelik müdahalelerin gerçekleştirilmesi gereklidir. 


\section{EXTENDED ABSTRACT}

\section{Stigmatization of People With Mental İllness: A Conceptual Study on the Affecting Factors and Their Effects On People}

Seval Bekiroğlu

Başkent University

From past to present, individuals with mental illness have been subjected to intense stigma. Having a mental illness in the community was seen as a sign of personal deficiency, weakness, deviation, low intelligence, unreliability or inadequacy. Individuals with mental illness were often seen as people with violence and unpredictable behavior. These kinds of negative attitudes and behaviors are present in the society, including the individuals themselves, their families, social environment and health professionals. Stigmatization styles are almost the same in different countries and regions. However, studies show that the stigmatization in the whole society generally occurs independent of the behavior of individuals with mental illness. In other words, people may have negative thoughts, attitudes and behaviors without having any experience with these people.

It is seen in the literature that stigmatization in individuals with mental illness is conceptualized as a complex phenomenon. Stamping by different authors; stereotypes, prejudice and discrimination (Corrigan and Kleinlein, 2005), information problems (ignorance or misinformation), attitude (prejudice) and behavioral problems (discrimination) (Thornicroft et al.2007), labeling, stereotyping, emotional reactions is defined with concepts such as loss of status and co-occurrence of discrimination (Świtaj, Chrostek, Grygiel, Wciórka, \& Anczewska, 2016). As Corrigan, Roe, and Tsang (2011) emphasized, it is important to distinguish basic terms such as attitudes, stereotypes, prejudice and discrimination that constitute its structure in understanding what stigmatization is in reality.

In the literature, it is seen that there are terminological differences in defining the types of stigmatization in individuals with mental illness. Stigma in some studies; it is defined in three levels as perceived, experienced and 
self-stigmatizing (Brohan, Elgie, Sartorius, \& Thornicroft, 2010; Gerlinger et al., 2013; Świtaj et al., 2016). In some studies; it is defined in three levels as structural / public, social and internalized stigmatization (Corrigan \& Watson, 2002; Hawke et al., 2013; Livingston \& Boyd, 2010). Gerlinger et al. (2013) dealt with stigmatization in two levels: social and personal stigmatization (perceived, experienced and self-stigmatized / internalized stigmatization).

Individuals with mental illness most often experience stigma associated with seeking psychological help. So much so that the more people with mental illness stigmatize themselves in the process of seeking help or think that they will be stigmatized by the society, the more they prevent themselves from seeking help. On the other hand, stigma decreases as the level of getting help increases. As a result of stigma, many individuals with mental illnesses prefer not to receive treatment or to stop treatment early. In this respect, stigma has the power to cause injustice and destructive consequences by damaging individuals with mental illness and therefore the society.

Stigma has many negative effects on individuals' quality of life, social functionality, self-esteem, anxiety level, depression, disease process, treatment process, social support and hope level. Effective intervention with stigmatization, which has serious effects on the lives of individuals, is among the important needs of individuals.

Important factors thought to affect the stigmatization of individuals with mental illness in the society; social environment, individual factors, factors related to the disease process and media. In anti-stigma interventions for individuals with mental illness, it is very important to consider these factors that are thought to affect stigmatization and to implement interventions to reduce their effects.

In anti-stigma interventions, the effect of individual factors such as stigma perception, sociodemographic characteristics, lifestyle and self-esteem on stigmatization should be taken into account. The important effect of factors related to the disease process on the stigmatization of these individuals, such as the diagnosis of the disease, the level of public awareness of the disease and its stigmatizing content, the duration of the disease, positive / negative symptoms, treatment environment, symptom severity, number of hospitalizations, and insight about the disease should be considered.

Social environment; culture, the physical environment in which people live, the education level of the people in the place of residence, the level of 
knowledge about mental illnesses, stigmatization by their relatives and the social support systems that individuals have.

The media is full of materials that stigmatize mental illnesses, especially schizophrenia. Stigmatization of schizophrenia is more common in the media. The news emphasizes that the cause of this in individuals who committed sensational crimes is a mental illness. Comedians use the shortcomings of individuals with mental disorders as a means of humor. Misinformation or repetition of comments in the media creates misperceptions about individuals with mental illness in the mind of the audience. In this respect, mass media, which have a strong persuasion and orientation effect, have a very important effect on stigmatization.

Both the factors affecting stigmatization and the effects of stigmatization on individuals emphasize the need for multidimensional implementation of anti-stigma interventions at micro, meszo and macro levels. Based on this, it can be said that the interventions to be carried out solely for the individual are not sufficient in combating stigmatization. It is necessary to carry out interventions for the individual and all systems (family system, health system, social environment, media) that the individual is connected to.

\section{Kaynakça / References}

Arkan, B., Bademli, K., ve Duman, Z. Ç. (2011). Sağlık Çalışanlarının ruhsal hastalıklara yönelik tutumları: Son 10 yldda Türkiye'de yapılan çalışmalar. Current Approaches in Psychiatry/Psikiyatride Guncel Yaklasimlar, 3(2), 214-231.

Arslantaş, H., Gültekin, B. K., Söylemez, A., ve Dereboy, F. (2010). Bir üniversite hastanesi psikiyatri polikliniğine ilk kez başvuran hastaların damgalamayla ilgili inanç, tutum ve davranışları. Adnan Menderes Üniversitesi Tip Fakültesi Dergisi, 11(1), 11-17.

Avcil, C., Bulut, H., ve Sayar, G. H. (2016). Psikiyatrik hastalıklar ve damgalama. Üsküdar Üniversitesi Sosyal Bilimler Dergisi, 2, 175-202.

Barış, Y. İ. (2002). Dünyada tüberkülozun tarihçesi. Türk Toraks Derg, 3, 338-340.

Baysal Doğanavşargil, G. Ö. (2013). Damgalanma ve ruh sağlığı. Arşiv Kaynak Tarama Dergisi, 22(2), 239-251.

Bekiroğlu, S., ve Demiröz, F. (2020a). Toplum ruh sağllğı merkezlerinden hizmet alan ağır ruhsal hastalığa sahip bireylerin algiladıkları sosyal damgalanmanın incelenmesi. Türkiye Sosyal Araștırmalar Dergisi, 24(1), 41-52. 
Bekiroğlu, S., ve Demiröz, F. (2020b). Toplum ruh sağlı̆̆ merkezlerinden hizmet alan ağır ruhsal hastallğa sahip bireylerin sosyal işlevselliğinin incelenmesi. Toplum ve Sosyal Hizmet, 31(3), 1053-1079.

Bilge, A., ve Çam, O. (2010). Ruhsal hastalı̆a yönelik damgalama ile mücadele. TAF Preventive Medicine Bulletin, 9(1), 71-78.

Brockington, I. F., Hall, P., Levings, J., ve Murphy, C. (1993). The Community's tolerance of the mentally ill. The British Journal of Psychiatry, 162(1), 93-99.

Brohan, E., Elgie, R., Sartorius, N., ve Thornicroft, G. (2010). Self-stigma, empowerment and perceived discrimination among people with schizophrenia in 14 European countries: The GAMIAN-Europe study. Schizophrenia research, 122(1-3), 232-238.

Ciftci, A., Jones, N., ve Corrigan, P. W. (2013). Mental health stigma in the Muslim community. Journal of Muslim Mental Health, 7(1), 17-32.

Corrigan, P. W.(1998). The impact of stigma on severe mental illness. Cognitive behavioral practice, 5(2), 201-222.

Corrigan, P. W., Roe, D., ve Tsang, H. W. (2011). Challenging the stigma of mental illness: Lessons for therapists and advocates: John Wiley ve Sons.

Corrigan, P. W., Watson, A. C., ve Barr, L. (2006). The self-stigma of mental illness: Implications for self-esteem and self-efficacy. Journal of social clinical psychology, $25(8), 875-884$.

Coşkun, S., ve Güven Caymaz, N. (2012). Bir Kamu ve özel psikiyatri hastanesine başvuran hastaların içselleştirilmiş damgalanma düzeyi yönünden karşllaştrılması. Journal of Psychiatric Nursing/Psikiyatri Hemsireleri Dernegi, 3(3), 121-128.

Çam, O., ve Bilge, A. (2011). Türkiye'nin Batısında yaşayan halkın ruhsal hastalığa ve hastalara yönelik inanç ve tutumlarının belirlenmesi. Yeni Symposium journal, 49(3), 131-140.

Çam, O., ve Bilge, A. (2013). Türkiye'de ruhsal hastalı̆ga/hastaya yönelik inanç, tutum ve damgalama süreci: Sistematik derleme. Psikiyatri Hemşireliği Dergisi, 4(2), 91-101.

Davis, L., ve Brekke, J. J. P. (2014). Social support and functional outcome in severe mental illness: The mediating role of proactive coping. 215(1), 39-45.

Dickerson, F. B., Sommerville, J., Origoni, A. E., Ringel, N. B., ve Parente, F. (2002). Experiences of stigma among outpatients with schizophrenia. Schizophrenia bulletin, 28(1), 143-155. 
Ersoy, M. A., ve Varan, A. (2007). Ruhsal hastalıklarda içselleştirilmiş damgalanma ölçeği Türkçe formu'nun güvenilirlik ve geçerlik çalışması. Türk Psikiyatri Dergisi, 18(2), 163-171.

Gary, F. A. (2005). Stigma: Barrier to mental health care among ethnic minorities. Issues in mental health nursing, 26(10), 979-999.

Gerlinger, G., Hauser, M., De Hert, M., Lacluyse, K., Wampers, M., ve Correll, C. U. (2013). Personal stigma in schizophrenia spectrum disorders: a systematic review of prevalence rates, correlates, impact and interventions. World Psychiatry, 12(2), 155-164.

Hasson Ohayon, I., Levy, I., Kravetz, S., Vollanski-Narkis, A., ve Roe, D. (2011). Insight into mental illness, self-stigma, and the family burden of parents of persons with a severe mental illness. Comprehensive Psychiatry, 52(1), 75-80.

Hawke, L. D., Parikh, S. V., ve Michalak, E. E. (2013). Stigma and bipolar disorder: a review of the literature. Journal of affective disorders, 150(2), 181-191.

Karidi, M. V., Stefanis, C. N., Theleritis, C., Tzedaki, M., Rabavilas, A. D., veStefanis, N. C. (2010). Perceived social stigma, self-concept, and self-stigmatization of patient with schizophrenia. Comprehensive Psychiatry, 51(1), 19-30.

Kleim, B., Vauth, R., Adam, G., Stieglitz, R.-D., Hayward, P., ve Corrigan, P. (2008). Perceived stigma predicts low self-efficacy and poor coping in schizophrenia. Journal of Mental Health, 17(5), 482-491.

Livingston, J. D., ve Boyd, J. E. (2010). Correlates and consequences of internalized stigma for people living with mental illness: A systematic review and metaanalysis. Social science medicine, 71(12), 2150-2161.

Lysaker, P. H., Tsai, J., Yanos, P., ve Roe, D. (2008). Associations of multiple domains of self-esteem with four dimensions of stigma in schizophrenia. Schizophrenia research, 98(1-3), 194-200.

Marrow, J., ve Luhrmann, T. M. (2012). The zone of social abandonment in cultural geography: on the street in the United States, inside the family in India. Culture, Medicine, Psychiatry research, 36(3), 493-513.

Oran, N. T., ve Şenuzun, F. (2008). Toplumda krılması gereken bir zincir: HIV/AIDS stigması ve baş etme stratejileri. Uluslararası İnsan Bilimleri Dergisi, 5(1), 1-16.

Özbaş, D., Kü̧̈ük, L., ve Buzlu, S. (2008). Ruhsal bozukluğu olan bireye sahip ailelerin hastallğa karşı tutumları. Düşünen Adam, 21(1-4), 14-23.

Phillips, M. R., Pearson, V., Li, F., Xu, M., ve Yang, L. (2002). Stigma and expressed emotion: a study of people with schizophrenia and their family members in China. The British Journal of Psychiatry, 181(6), 488-493. 
Sen, F. S., Taskin, E. O., Özmen, E., Aydemir, Ö., ve Demet, M. M. (2003). Türkiye'de kirsal bir bölgede yasayan halkin depresyona iliskin tutumlari. Anadolu Psikiyatri Dergisi, 4(3), 133-143.

Sibitz, I., Amering, M., Unger, A., Seyringer, M., Bachmann, A., Schrank, B., . . . Woppmann, A. (2011). The impact of the social network, stigma and empowerment on the quality of life in patients with schizophrenia. European Psychiatry, 26(1), 28-33.

Świtaj, P., Chrostek, A., Grygiel, P., Wciórka, J., ve Anczewska, M. (2016). Exploring factors associated with the psychosocial impact of stigma among people with schizophrenia or affective disorders. Community mental health journal, 52(3), 370-378.

Şen, F., Taşkın, E., Özmen, E., Ademir, Ö., ve Demet, M. M. (2003). Türkiye'de kırsal bir bölgede yaşayan halkın depresyona ilişkin tutumları. Anadolu Psikiyatri Dergisi, 4(3), 133-143.

Taskin, E. O., Seyfe Sen, F., Aydemir, O., Demet, M. M., Ozmen, E., ve Içelli, I. (2002). Türkiye'de kirsal bir bölgede yasayan halkin sizofreniye iliskin tutumlari. . Türk Psikiyatri Dergisi, 205-214.

Taşkın, E. O., Şen, F. S., Özmen, E., ve Aydemir, Ö. (2006). Kırsal kesimde depresyonlu hastalara yönelik tutumlar: sosyal mesafe ve etkileyen etmenler. Türkiye'de Psikiyatri, 8(1), 11-17.

Taşkın, O. (2007). İçselleştirilmiş damga ve damgalanma algısı . O. Taşkın (Ed.), Stigma Ruhsal Hastalklara Yönelik Tutumlar ve Damgalama içinde (s. 31-40): Meta Basım ve Matbaacilik.

Tel, H., ve Ertekin Pınar, Ş. (2012). Ayaktan izlenen psikiyatri hastalarında içselleştirilmiş damgalama ve benlik saygisi. Journal of Psychiatric Nursing/Psikiyatri Hemsireleri Dernegi, 3(2), 61-66.

Torrey, E. F., ve Yolken, R. (2010). Psychiatric genocide: Nazi attempts to eradicate schizophrenia. Schizophrenia Bulletin, 36(1), 26-32.

Üçok, A. (2003). Şizofreni hastası neden damgalanır? Klinik Psikiyatri,, 1, 3-8.

Üstündağ, M. F., ve Kesebir, S. (2013). İki uçlu bozuklukta içselleştirilmiş damgalanma: Klinik özellikler, yaşam kalitesi ve tedaviye uyum ile ilişkisi. Türk Psikiyatri Dergisi, 24, 1-9.

Werner, P., Stein-Shvachman, I., ve Heinik, J. (2009). Perceptions of self-stigma and its correlates among older adults with depression: a preliminary study. International Psychogeriatric, 21(6), 1180-1189. 
West, M. L., Yanos, P. T., Smith, S. M., Roe, D., ve Lysaker, P. H. (2011). Prevalence of internalized stigma among persons with severe mental illness. Stigma research action, 1(1), 3-10.

World Health Organization. (2011). World report on disability.

Yang, L. H., Kleinman, A., Link, B. G., Phelan, J. C., Lee, S., ve Good, B. (2007). Culture and stigma: Adding moral experience to stigma theory. Social Science ve Medicine, 64(7), 1524-1535.

Yanos, P. T., Roe, D., Markus, K., ve Lysaker, P. (2008). Pathways between internalized stigma and outcomes related to recovery in schizophrenia spectrum disorders. Psychiatric services, 59(12), 1437-1442.

\section{Kaynakça Bilgisi / Citation Information}

Bekiroğlu, S. (2021). Ruhsal hastalığa sahip bireylere yönelik damgalama:Etkileyen faktörlere ve bireyler üzerindeki etkilerine dair kavramsal bir çalışma. OPUS-Uluslararası Toplum Araştırmaları Dergisi, 17(33), 595-618. DOI: 10.26466/opus.825384 